\title{
Relationship between physical activity and work efficiency among kindergarten employees
}

\author{
Anja Andrenšek', Matej Plevnik² \\ I Community Health Centre Brežice, Centre for Health Enhancement, Cesta bratov Milavcev I8, \\ 8250 Brežice, Slovenia \\ ${ }^{2}$ University of Primorska, Faculty of Health Sciences, Polje 42, 6310 Izola, Slovenia \\ anja.andrensek@gmail.com; matej.plevnik@fvz.upr.si
}

\begin{abstract}
Introduction: People who live a healthy lifestyle are less likely to develop chronic diseases, such as type 2 diabetes, obesity, hypertension and also osteoporosis, cancer, increased level of cholesterol, depression, anxiety, etc. The purpose of our study was to examine the correlation between physical activity and work efficiency among different job positions in kindergarten. Methods: The Global Physical Activity Questionnaire and the Work Ability Index Questionnaire were used to assess the intensity and the quantity of PA and an individual's work efficiency. Resuts: The comparison between the groups shows that the highest physical activity at work is assessed by the employees in support services, this group also best evaluates their ability to work, 54\% describe it as excellent. The amount of physical activity is statistically significantly related to the work efficiency index only in the group of teacher assistants. Discussion and conclusions: The promotion of health protection at the workplace must be adapted to the needs of each group of employees in kindergartens. It is also recommended to encourage regular physical activity of all groups of employees.
\end{abstract}

Keywords: kindergarten, physical activity, work ability, workload, health enhancement

\section{Introduction}

Regular physical activity has a proven positive effect on physical and mental health and it also has an impact on the improved work efficiency and the overall quality of life. Reducing sedentary behaviour and maintaining regular physical activity, even if it does not meet the recommendations for the amount of physical activity, affects health, has a positive effect on preventing premature death and reducing the chances of various health risks. Regular physical activ- 
ity, regardless of age, gender, chronic diseases and limitations present, reduces the incidence of cardiovascular disease, stroke, cancer, type 2 diabetes, obesity and osteoporosis (Warburton and Brendin, 2016).

Kindergarten brings together different groups of employees, who face different types of workload in their work: (i) kindergarten teachers, (ii) teacher assistants, (iii) administration and management of the kindergarten and (iv) employees in support services (cooks, cleaners, janitors). The most frequently studied groups of employees in kindergarten are teachers and teacher assistants. Kindergarten teachers/assistants perform a variety of work tasks that include teaching, supervision, hygiene maintenance tasks, as well as nutrition assistance. The workload is described from a metabolic point of view as low-intensity activity (Grant et al., 1995). Frequent incorrect postures and positions, fast work pace, insufficient amount of rest and lifting heavy loads increase the risk of musculoskeletal problems (Punnett and Wegman, 2004). In addition to physical exertion, teachers/assistants are also exposed to high levels of psychological stress. Teachers/assistants report overwork, time pressure and high responsibility; nevertheless, they find their work interesting (Čecho, Švihrová, Čecho, Novák and Hudečková, 2019). The purpose of our study was to determine the relationship between the level of physical activity and the work efficiency of kindergarten employees.

\section{Methods}

The study was conducted in September 2019 in cooperation with the Centre for Health Enhancement Piran and two kindergartens in the Municipality of Piran. It involved 73 kindergarten employees (teachers $n=24$; assistants $n=27$; administration $n=5$; support services $n=17$ ). To assess the intensity and quantity of PA and an individual's work efficiency, we used the Global Physical Activity Questionnaire (WHO, n. d.) and the Work Ability Index Questionnaire (European Agency for Safety and Health at Work, n. d.). The analysis of the results was performed in Microsoft Excel 2016 (Microsoft Corporation, Redmond, Washington, USA) and in SPSS (SPSS statistics 26, IBM, New York, USA), using methods of descriptive statistics and the analysis of correlations and differences. The statistical significance was set at $\mathrm{p}<0.05$.

\section{Results}

Recommendations on the amount of daily physical activity (WHO, 2011) are met by $95.2 \%$ of kindergarten teachers, $83.4 \%$ of assistants, $33.3 \%$ of employees in administration and $94.2 \%$ of employees in support services (Figure 1). The comparison between the groups shows that the highest physical activity at work is assessed by the employees in support services (Kruskal-Wallis $\mathrm{H}(3)=$ $16.667, \mathrm{p}=0.001$ ). 


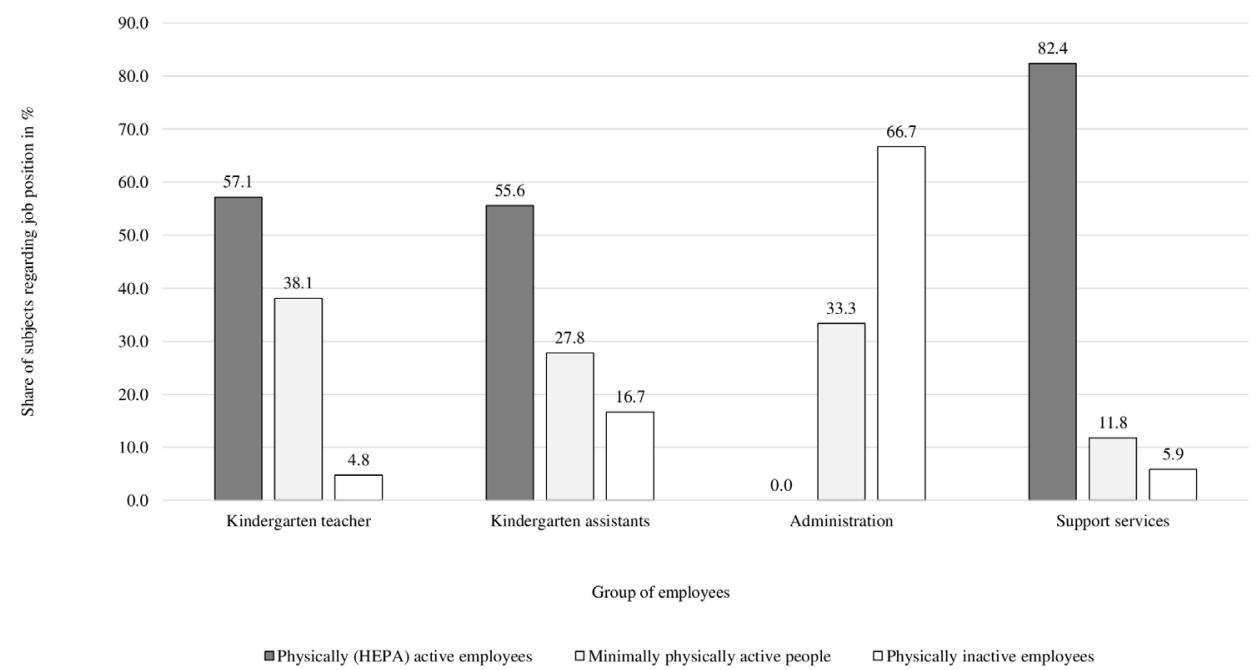

Figure 1: Physical activity of employees according to WHO recommendation (WHO, 2011) HEPA (Health enhancing physical activity) (WHO, 2020) recommendation

The group of employees in support services also best evaluates their ability to work; $54 \%$ describe it as excellent (Figure 2).

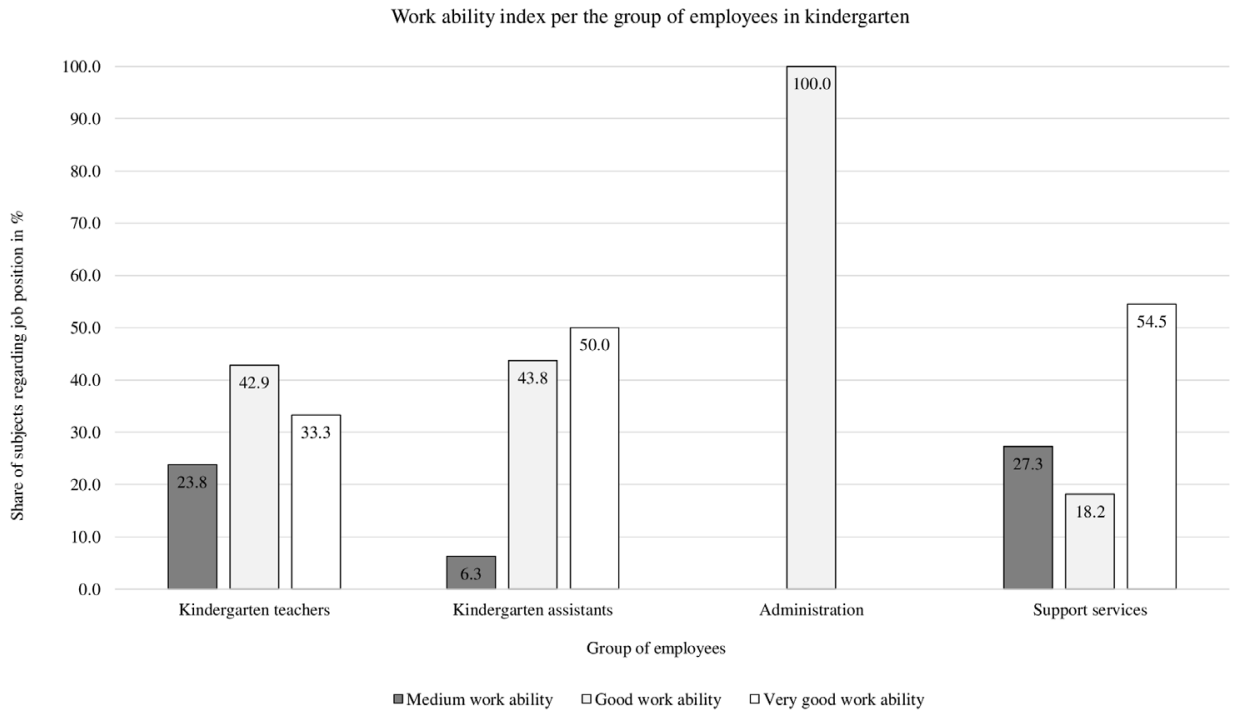

Figure 2: Work ability index per the group of employees in kindergarten

Very good work ability is assessed by $33.3 \%$ of kindergarten teachers, $50 \%$ of kindergarten assistants and $54.5 \%$ of employees in support services; howev- 
er, the number of employees should also be taken into account. The amount of physical activity is statistically significantly related to the work efficiency index only in the group of teacher assistants $\left(\chi^{2}(2)=8.878, \mathrm{p}=0.012\right)$.

\section{Discussion}

Research done in kindergarten is generally performed on kindergarten teachers and assistants regarding their health status (Wirth et al., 2016), voice health and risk factors for voice loss (Helidoni et al., 2012), mental health (Čecho et al. 2019), musculoskeletal disorders and the connection between musculoskeletal disorders and mental health (Ono et al., 2002; Pirbalouti et al., 2017) and regarding ergonomic adjustments of workplace (Burford et al., 2017). Our study revealed the level of physical activity and offered an insight into the working ability among different groups of employees in kindergarten. We noticed that only in the group of teacher assistants, the amount of physical activity was statistically significantly related to the work efficiency, though we expected to find correlations in all groups of employees. Regular physical activity maintains solid fitness, better mental health and maintains or improves work efficiency. However, regular physical activity is important also for the evaluation of competency for their work among kindergarten teachers/assistants. Physically active preschool teachers evaluate competencies for planning, organising, implementing and evaluating physical activities higher (Retar and LepičnikVodopivec, 2017). Regular physical activity of kindergarten teachers/assistants is not only important regarding health and the overall quality of life but also as a factor of their perception of their own competencies for professional work.

\section{Conclusions}

Kindergarten brings together different groups of employees who face different types of workload in their work. In accordance with the daily workload, the promotion of health protection and enhancement at the workplace must be adapted to the needs of each group of employees. It is also recommended to encourage regular physical activity of all groups of employees in kindergarten.

\section{References}

BURFORD, E.-M., ELLEGAST, R., WEBER, B., BREHMEN, M., GRONEBERG, D., SINN-BEHRENDT, A. and BRUDER, R., 2017. The comparative analysis of postural and biomechanical parameters of preschool teachers pre- and post-intervention within the ErgoKiTa study. Ergonomics, vol. 6o, no. 12, pp. 1718-1729.

ČECHO, R., ŠVIHROVÁ, V., ČECHO, D., NOVÁK, M. and HUDEČKOVÁ, H., 2019. Exposure to mental load and psychosocial risks in kindergarten teachers. Zdravstveno varstvo, vol. 58, no. 3, pp. 120-128.

EUROPEAN AGENCY FOR SAFETY AND HEALTH AT WORK, n. d.. Work ability index [online]. [viewed 13 December 2019]. Available from: https:// 
healthy-workplaces.eu/previous/all-ages-2016/en/tools-and-publications/ practical-tools/work-ability-index

GRANT, K., HABES, D. and TEPPER, A., 1995. Work activities and musculoskeletal complaints among preschool workers. Applied ergonomics, vol. 26, no. 6, pp. 405-10.

HELIDONI, M., MURRY, T., CHLOUVERAKIS, G., OKALIDOU, A. and VELEGRAKIS, G., 2012. Voice risk factors in kindergarten teachers in Greece. Folia phoniatrica et logopaedica, vol. 64, no. 5, pp. 211-216.

ONO, Y., IMAEDA, T., SHIMAOKA, M., HIRUTA, S., HATTORI, Y., ANDO, S., ... TATSUMI, A., 2002. Associations of length of employment and working conditions with neck, shoulder and arm pain among nursery school teachers. Industrial health, vol. 40, no. 2, pp. 149-158.

PIRBALOUTI, M. G., SHARIAT, A., SANGELAJI, B., TAGHAVI, M. and KAMALIYEH, N. G., 2017. Prevalence of musculoskeletal disorders and its relation to depression among workers in kindergarten. Work, vol. 58, no. 4, pp. 519-525.

PUNNETT, L. and WEGMAN, D. H., 2004. Work-related musculoskeletal disorders: the epidemiologic evidence and the debate. Journal of electromyography and kinesiology: Official journal of the international society of electrophysiological kinesiology vol. 14, no. 1, pp. 13-23.

RETAR, I. and LEPIČNIK-VODOPIVEC, J. (2017). Kompetentnost vzgojiteljev za inovativno gibalno poučevanje. Pedagoška obzorja: časopis za didaktiko in metodiko 32(1): 17-32.

WARBURTON, D. E., \& BREDIN, S. S. (2016). Reflections on physical activity and health: what should we recommend?. Canadian Journal of Cardiology, 32(4), 495-504.

WIRTH, T., KOZAK, A., SCHEDlbAUER, G. and NIENHAUS, A., 2016. Health behaviour, health status and occupational prospects of apprentice nurses and kindergarten teachers in Germany: a cross-sectional study. Journal of occupational medicine and toxicology, vol. 11, no. 26.

WORLD HEALTH ORGANIZATION, 2011. Information sheet: global recommendations on physical activity for health 18-64 years old [online]. [viewed 31 July 2019]. Available from: https://www.who.int/dietphysicalactivity/physical-activity-recommendations-18-64years.pdf?ua $=1$

WORLD HEALTH ORGANIZATION, n. d. Global physical activity questionnnaire (GPAQ): analysis guide [online]. [viewed 31 July 2019]. Available from: https://www.who.int/ncds/surveillance/steps/resources/ GPAQ_Analysis_Guide.pdf 